\title{
Jewish medical ethics - a brief overview
}

\author{
Sir Immanuel Jakobovits Chief Rabbi of the British Commonwealth
}

\section{Editor's note}

This paper outlines the traditional fewish approach to medical ethics, as perceived by the Chief Rabbi of the British Commonwealth, himself an academic specialist in this field. It is based on a'St Paul's Lecture' given to the London Diocesan Council for Christian Fewish understanding.

In medical ethics converge two of the Jewish people's most notable contributions to the progress of humanity: medicine and ethics. From the beginning, our people have shown a special concern with the healing art. Already the Bible includes in its religious legislation some revolutionary concepts of preventive medicine and public health. In the Talmud we find, among the numerous medical references almost 2,000 years ago, the earliest mention of such innovations as artificial limbs, some form of artificial insemination, oral contraceptives and Caesarian operations on living mothers. Many authors of the Talmud themselves practised medicine. They were succeeded by what became, in the Middle Ages, the common phenomenon of the rabbi-physician. Indeed, it is estimated that over one-half of the best-known rabbinical scholars and authors - philosophers, poets, exegetes, grammarians as well as rabbis - in medieval times were physicians by occupation; men like Maimonides, Nachmanides, the Ibn Ezras, Ibn Tibbons and countless others.

These historical antecedents no doubt contributed significantly to the extraordinary predilection among Jews for a medical career in modern times. Only an attitude conditioned by centuries of nurture could have produced such a disproportionate preoccupation with medicine as to have enabled Jews to receive some 20 per cent of all Nobel prizes for medicine - a proportion more than $\mathbf{4 0}$ times the ratio of Jews in the world! Likewise most leading medical historians were Jews; one recalls names like Max Neuberger, Arturo Castiglioni, Charles Singer of this country, and Joshua Leibowitz and Sussman Muntner of Israel.

\section{Key words}

Jewish medical ethics; history of Jewish medicine; abortion; contraception; euthanasia; experiments on humans; genetic engineering; medical ethics training.

\section{Emphasis on ethics}

Paramount throughout this long and highly creative association between Judaism and medicine has been the emphasis on ethics as their common denominator. Building materials for the imposing edifice of Jewish medical ethics came from all strata of our religious literature, while the architects were legal experts, who, as already noted, often combined rabbinical and medical experience. The Bible provided the foundations: the sanctity and dignity of human life, the religious duty to preserve health, an uncompromising opposition to superstition and irrational cures, including faith-healing, a rigid code of sexual morality, and many basic definitions of moral imperatives in medical practice, including the rights of the dead.

By the way, these rights, as defined in Deuteronomy, expressly extend even to executed criminals, and I need hardly stress how significantly this provision alone contrasts with the callousness of other legislations, ancient and modern, which treats the bodies of such criminals and of so-called 'unclaimed persons' as res nullius and denies them the claim to dignified burial. The impact of the biblical tradition on the development of medical ethics in Western society may be understood when it is contrasted with the Code of Hamurabi and other ancient legislations which provided, for instance, for the amputation of a doctor's arm if he proved unsuccessful in an operation on his patient!

On these biblical foundations, the Talmud (the depository of the 'Oral Law' finally edited about $500 \mathrm{C} \mathrm{E}$ ) established the legal framework in virtually all fields of medical ethics, setting forth the main principles on such problems as abortion, euthanasia, contraception, sterilisation, malpractice claims, etc. The Talmud, followed by the great codes of Jewish law, even enacted certain eugenic laws against marriages suspected to result in physically or morally diseased children. Anyone who has read the famous Oath of Asaph Judaeus (7th century) or the medical writings of other early Jewish notables in the history of medicine will recognise at once how profoundly the spirit of the Bible and the Talmud suffused their ethical outlook. Little wonder that there never existed a Jewish form of the Hippocratic Oath, though there were Christian and 
Mohammedan as well as pagan versions of it. Jews simply fell back on their own ethical heritage.

And it was left to the voluminous rabbinical responsa, issued in increasing profusion over the past 1000 years, to interpret and apply these principles in the light of contemporary conditions and the advance of medical knowledge and techniques. There are now being published annually, notably in Israel, hundreds of such rabbinical responsa or verdicts - ranging over the entire gamut of ethical problems in medicine, from transplants to artificial insemination, and from experimentation on humans or animals to autopsies. The responsa serve as case-law in the evolution of modern Jewish law. As a consensus gradually emerges from the many often conflicting judgments given, this consensus is recognised as a valid precedent and embodied in the accepted corpus of rabbinic law.

\section{Abortion and contraception}

Let me give just one example to illustrate this process in rough outline. The Bible does not specifically deal with either criminal or therapeutic abortion. But in legislating on the liability for assaulting a pregnant mother and causing a miscarriage, the text in the Book of Exodus (21:22) implies that the destruction of an unborn child is not culpable as murder, and that the fetus does not, therefore, enjoy the same absolute title to life as an existing human being. The Talmud takes this an important step further by ruling in favour of an embryotomy where a difficult delivery otherwise threatens the mother's life. In any mortal conflict between mother and child, the ruling insists that her life enjoys priority, if necessary at the deliberate expense of the child, provided its head or the greater part of its body has not yet emerged from the birthcanal (which is the legal definition of birth). Judaism, therefore, in contrast to Catholic teaching, would regard it as a grave offence against the sanctity of life to allow a mother to perish in order to save her unborn child. In other words Jewish law distinguishes between potential (unborn) life and existing or independent (born) life, only the latter being absolute in value and therefore inviolate, rendering its destruction an act of murder. Nevertheless, the unborn child, in different stages from the moment of conception, enjoys a very sacred title to life which can or must be set aside only in the most exceptional circumstances.

This and some other Talmudic principles were then used in the numerous rabbinical responsa of the past few centuries (and especially of very recent times) to provide judgments in more complicated circumstances, for instance, in cases of rape or incest, or of suspected deformities in the child resulting from the effects of rubella (German measles) or drugs like thalidomide during early pregnancy. Often differences of opinion still remain unresolved. For example, while a leading member of the Israel Chief Rabbinate, a specialist on medicine in the Halacha (Jewish religious law), is inclined to permit the abortion of an embryo in the earliest stage of gestation if the mother has contracted German measles, the late Chief Rabbi Unterman of Israel adamantly opposed the destruction of any potential human life unless the mother's life were in jeopardy.

But virtually all responsa recognise only a strictly medical motivation for abortion, and they would not sanction the termination of a pregnancy unless there were some grave physical, or even psychiatric, hazard to the mother's life, however remote, provided every such capital judgment - which literally determines whether a human life is 'to be or not to be' - is most scrupulously considered on the strength of the best available medical evidence and in consultation with competent moral experts.

Similar considerations govern the attitude to birth control. Where genuine fears exist, attested by reliable medical opinion, that a renewed pregnancy might possibly cause some serious risk to the mother, rabbinical verdicts on the use of contraceptive precautions would generally be liberal. Once again, of course, each case would have to be judged on its own merits, and Jewish law would make some distinction between different types of devices, oral contraceptives being regarded as the least objectionable. But purely social or economic reasons, let alone considerations of sheer convenience, would never be regarded as a valid indication for the artificial frustration of the act and duty of procreation. For legal purposes, ie to override or modify religious laws, Judaism would therefore not unreservedly accept the World Health Organisation (WHO) definition of health 'as a state of physical, mental and social wellbeing'. While it naturally seeks to promote the social health of society and its members, by numerous laws and enactments designed to advance human welfare in every sphere, social and economic considerations by themselves do not automatically suspend religious or moral imperatives in the same way as purely medical factors do.

The most popular argument commonly advanced in connection with both abortion and birth control, that is, the artificial prevention or termination of a pregnancy, is the fear of 'population explosion'. Quite frankly, if the nations affected - maybe the Indians, or the Chinese, or some South American peoples - were to ask me as a rabbi for moral advice on how to cope with their very real problem of a teeming population outrunning available food supplies, I would not find it too difficult to provide an answer. The fear of starvation is certainly a threat to life which could easily justify certain measures to control population growth. But so far these nations have not asked me for my advice, and I would be quite happy if I succeeded in prevailing on Jews to accept the directives of Jewish ethics.

Jews are facing today, and have always faced in the past, numerous problems and difficulties. But population explosion is not one of them. On the contrary, we face the opposite problem of population shrinkage. Our birth-rate both here and throughout our dis- 
persion, and notably in Israel, is appreciably lower than that of the general population around us. In fact, we hardly produce enough to maintain our existing numbers, let alone to replenish the calamitous losses we sustained in the Nazi Holocaust with the destruction of one third of our people. And out of the sparse numbers that we do produce we lose too many, through drift and assimilation. The result is that, for the first time in our millennial history, we are facing and widely discussing the problem of Jewish survival.

Hence, for us the problem of abortion and contraception, quite apart from the intrinsic moral considerations involved, is of paramount demographic significance to the future of our people.

\section{Sanctity of human life}

In more strictly professional terms, Jewish medical ethics is also often at variance from the norms developed in secular law and common practice. To take a classic example, if one sees a two-year-old child drowning in a foot of water, neither a doctor nor any other passer-by is under an obligation to help the child, at least not in British law. In Jewish law, such conduct violates the Biblical precept: 'You shall not stand upon your neighbour's blood'. Hence, the Shulchan Aruch (the final codification of Jewish law of the 16th century) rules that to engage in medicine is a mitzvah, a religious precept or ideal, and any doctor who refuses to attend to those in need is guilty of bloodshed, just as a qualified rabbi who fails to practise his vocation is held responsible for the spiritual victims slain by his default.

Worse still - dare I mention this - the Shulchan Aruch debars physicians, engaged as they are in the fulfilment of a religious duty, from receiving payment for their skills, just as rabbis were expected to give their religious services free - a practice commonly observed until the rabbinate became professionalised in fairly recent centuries. But doctors may derive some relief and profit - from the omission of this rule about physicians in the code of Maimonides who was, of course, himself making a living from medicine because he refused to be paid for his rabbinical work. Physicians and rabbis are also treated alike in respect of their liability for damages caused by negligence or errors of judgment.

In a brief historical survey of such wide-sweeping dimensions and subject matter, I am forced to limit my references to some more modern issues to the barest outline of the principal conclusions.

In the matter of euthanasia, for instance, any deliberate act to hasten death, whether with or without the patient's consent, is incompatible with the Jewish understanding of the sanctity of life. Judaism regards every human life (from the moment of birth) as being of infinite value. Infinity, by definition, is indivisible, so that any fraction of life, whether 10 years or a minute, whether healthy, crippled or even unconscious, remains equally infinite in value. By attacking the ebbing life of a terminal patient because it is deemed worthless, we would rob all human beings of their absolute claim to life, making it merely relative - to their expectancy of life, or their state of health, or their usefulness to society, or to any other arbitrary criterion. No two human beings would be equal in value. For their worth, being reduced to a finite scale, would depend on any variety of physical or social means tests. Consequently, Jewish law brands direct euthanasia as murder. But under certain carefully defined conditions, it might not require the physician to prolong the agony by artificial or 'heroic' methods, permitting him to withdraw such treatment in completely hopeless cases of lingering life. But on the precise verdict in these cases there is still some debate in current rabbinical writings.

And just as infinity cannot be reduced by division, making 'half' a life any less valuable than a full life, so infinity cannot be increased by multiplication, making a million lives any more precious than one life. We would therefore never be justified in sacrificing or deliberately risking a single life however many others may thereby be saved, and it is wrong to subject people, even with their informed consent, to possibly hazardous medical experiments, unless the subjects themselves might be helped in a gamble to save their lives in the absence of any tried cures. In other words, experiments involving possible risks of life must not be performed even on volunteers who are healthy; such risks could only be justified if the subjects themselves would be the beneficiaries were the experiment to succeed.

Similar considerations apply to the present state of transplant surgery. While Jewish law raises no objection to corneal grafts, with certain safeguards, nor indeed to any organic transplants, in principle, it views with grave concern the indecent haste with which doctors and hospitals have competed in these premature operations at the cost of scores of lives and of false hopes raised and dashed in thousands of sufferers. Jewish law insists, firstly, that no vital organ be removed from a donor until death is definitely established by the actual cessation of all essential life functions, including particularly respiration and pulsation, and not merely by what is termed 'clinical death', such as irreversible brain damage. It insists, secondly, that such operations must not be continued unless they have passed the purely experimental stage and offer recipients a reasonably hopeful prognosis.

It would be wrong, therefore, to manipulate one life, even if only maintained by artificial life-supports, for the sake of another - for instance, by switching off the respirator sustaining the 'clinically dead' donor (whose heart is still beating) when the recipient is ready to receive the former's organ. One would have to await complete death either by allowing the machine to run out on its own or by not re-applying it, but not by an action calculated to induce death, ie turning the switch. As for the recipient, such operations may only be carried out after they have proved successful on animals, and provided always that the sole object of performing such operations on humans is to save the life of 
the patient at hand and not merely to assemble research data and experience for the treatment of future patients. In the absence of any known or proven cure, any high-risk treatment or experiment can only be sanctioned if the subject himself is the intended beneficiary should the procedure prove successful.

Some years ago, on a visit to Cape Town, I had the opportunity of a fascinating discussion on the subject with the celebrated pioneer of heart transplant surgery, Dr Christian Barnard. We found ourselves not unexpectedly considerably at variance in our definition of death as relevant to the excision of the donor's heart. I found his attitude, in favour of an earlier moment of time, certainly no less dogmatic than mine in attributing an intrinsic value to life so long as it was not yet entirely extinct.

\section{Challenges of a technological age}

In our technological age, medicine, like science generally, threatens to turn homo sapiens into homo mechanicus, treating him with his incomparable nature and dignity as if he were a soulless machine. In our push-button world scientists, technicians and public relations experts have usurped philosophers, thinkers and men of the spirit in determining the patterns of human behaviour and the objectives of man's destiny. In this new dispensation, the physician, too, is wielding ever greater power. Human life is now at his bidding. He can generate it out of test-tubes and terminate it out of syringes. He can regulate the size of families by contraceptive advice and feticidal operations, and he can sway emotional responses by drugs and psychiatric treatment. Together with other scientists he will increasingly control human life, but the crucial question is, who will control the controllers? As the delicately balanced fusion of body, mind and soul and their interplay in human life, man requires a similar co-ordination of expert opinion in all three fields when delicate decisions regarding his well-being have to be taken. In respect of the soul, if not the mind, this should include moral specialists - whether ethicists for Humanist patients, moral theologians for Catholics, or masters of Jewish law for Jews.

'Genetic engineering' may soon surrender the very building-blocks of life itself to the arbitrary whims of technical experts. Not so long ago, Dr James Shapiro, a leading researcher at Harvard University, said in a widely-publicised statement: 'The prospect is that science will learn how to create a number of identical human beings exactly as you would breed prize cattle', or, I might add, as you manufacture cars on assembly lines. This frightening statement precisely epitomises the challenge to medical ethics: In our blind march to mechanical perfection, shall we reduce man to prize cattle, or to mass-produced machines? New medical skills and insights, such as spare-part surgery and genetic research, may open up a wonderful chapter in the history of healing. But without strict moral controls and ethical guidelines they may also herald irretrievable disaster through man's encroachment upon nature's preserves and the danger of assessing human beings by their value as tool parts or sperm-donors or living incubators or guinea pigs when they are alive, and as medical textbooks or suppliers of ersatz organs when they are dead.

In my fairly frequent opportunities to address medical schools or professional groups on the subject, in the UK or in America and especially in Israel I therefore never tire of advocating the inclusion of formal instruction in medical ethics in the training of doctors, nurses and hospital staffs. No student of medicine or nursing should be deemed qualified without being familiarised, in mandatory courses, with the ethical principles governing the healing art. Such training should include some detailed introduction into the relevant religious teachings likely to dictate the patients' commitments. Such instruction should not be left to a few haphazard extra-mural lectures or to incidental remarks by conscientious tutors. Of course, I am particularly anxious to see an Academic Chair in Medical Ethics established in the land which has inspired the advance of civilisation and the moral law throughout the world.

Nineteen hundred years ago our people, sustaining blows which would have proved fatal to any other nation, decided to prove that where there is life there is hope, preferring to live in abject misery and suffering rather than to choose the euthanasia of a heroic death with glory which they could have had for the asking. Because of that choice, we are here today. May we now help a stricken humanity likewise to choose a life sustained by the supremacy of the spirit over the body, of ethics over mechanics, so that mankind may be restored to universal health. 